\title{
THE IMPACT OF HALAL AT THAYYIB AND CONSUMPTION ETHICS ON ECONOMIC GROWTH: AN ECONOMIC TAFSIR OF AL-BAQARAH 168
}

\author{
Taqiyah D. Insani ${ }^{1}$, Abdul W. Al-Faizin ${ }^{2}$ and Muhammad N.H. Ryandono ${ }^{3}$ \\ 1 Universitas Airlangga, Indonesia, taqiyah.dinda@gmail.com \\ 2 Universitas Airlangga, Indonesia, alfaiz165@gmail.com \\ 3 Universitas Airlangga, Indonesia, muhammadnafik@feb.unair.ac.id
}

\begin{abstract}
Consumption that is a determinant variable of Indonesian economic growth often ignores the negative externalities of objects consumed. In addition, often the commands in the Qur'an have not been understood in depth in that the substance has not been successfully raised. This paper attempts to examine the concept of halal from sūrah al- Baqarah: 168 by using the tafsīr method to analyze its impact on economic growth. The paper is a qualitative exploration using content analysis that combines tafsir bi alra'yi with tafsìr bi al-ma'thūr. By using economic interpretation, this paper was able to further discuss consumption as one of the main pillars of Islamic economics, especially with regard to the five basic needs in the maqāsid sharia. Three main aspects stated by Halal At Thayyib are the main condition of the object of consumption in Islam. First, the object does not contain illicit elements. Second, it contains benefits that have a positive impact. Third, it does not contain anything that is harmful to the body and mind. This study also found that in terms of macro consumption, Halal At Thayyib is able to improve quality economic growth by eliminating negative externalities.
\end{abstract}

Keywords: Halal, Thayyib, Economic Tafsir, Economic Growth.

JEL Classification: E21; E71; H23; I15.

\author{
Article history: \\ Received : October 27, 2019 \\ Revised : July 15, 2019 \\ Accepted : July 25, 2019 \\ Available online : July 30, 2019 \\ https://doi.org/10.21098/jimf.v5i2.1071
}




\section{INTRODUCTION}

\subsection{Background}

Consumption activities cannot be separated from human life; for, it is well known as a direct fulfillment of life needs. Some indices or measurements used to see poverty levels refer to consumption activities. As mentioned by the theory of the vicious cycle of poverty proposed by Gunnar Myrdal in economic development, poverty is not a problem of lack of capital from the poor. Further than that, poverty is caused by not meeting the basic needs of the poor, especially in terms of the nutritional quality of the poor. He further explained that poor conditions originated from low income resulting in the lack of quality of nutrition. The low quality of nutrition causes low health, which then causes low productivity. This low productivity causes low income, and in turn causes poverty. Poverty is a concern of many governments in the world because it is closely related to economic growth. Many studies also confirm that poverty is an important factor in economic growth (Kheir, 2018; Sasmal \& Sasmal, 2016; Sehrawat \& Giri, 2016).

The discussion of consumption activities often ignores externalities. Externality is a side effect of a certain party's actions towards another party, both beneficial and adverse (Petach \& Tavani, 2019). Externalities occur only when the actions of a party have an impact on another party without compensation. In the event of an externality that causes this market failure, the government is expected to intervene in view of one of the functions of the government as a stabilizer in the economy.

Islam has a deeper view of consumption activities. Islam has detailed rules regarding consumption activities, which lead to the halal concept. Many studies of halal consumption activities have been carried out, but more studies discuss determinant factors in the consumption of halal products (Ali, Xiaoling, Sherwani, \& Ali, 2017; Arsil, Tey, Brindal, Phua, \& Liana, 2018; Asnawi, Sukoco, \& Fanani, 2018; Ayyub, 2015; Omar, Zainol, Thye, Ahmad Nordin, \& Nazri, 2017; Shahid, Ahmed, \& Hasan, 2018). Very little research has been done that seeks to explore more deeply about the concept of halal in a practical manner in that it is more applicable to be utilized. This research is one of the first that seeks to explore the practical concept of halal by using one of the verses in the Quran, namely verse 168 of chapter 2 (Al Baqarah).

In addition, this study uses a suitable research approach to discuss the meaning of the verse of the Quran, i.e., the tafsir method that has been used by Ulam $\bar{a}$ ' to explore the laws and wisdom from Quran which is part of a qualitative research approach. This paper analyzed the meaning of Lafad mentioned in sürah al-Baqarah: 168. As far as semantic analysis is concerned, the authors explore some concepts that exist in sūrah al-Baqarah: 168. This analysis refers to some book of tafsir both of classical and contemporary books. Similarly, the authors combine the tafsīr bi al-ma' thūr book and tafsīr bi al-dirāyah book.

The results of this study can eventually be utilized both for the government, academics, practitioners, and society because the halal concepts to be discussed in this study will have a common thread on economic growth. 


\subsection{Objective of the Study}

The objective of this study is to analyze how the concept of halal based on sūrah al-Baqarah: 168 as the main source of Islamic law.

\section{LITERATURE REVIEW}

\subsection{Consumption Theory and Halal At Thayyib}

Halal is anything that benefits and does not cause harm to the body, mind and religion (Abdelali, 2019). Muslim consumer behavior and corporate practices point towards perspectives that reframe halal standards. The halal paradigm demonstrates an area where cognitive, affective and conative decision-making patterns are affected by risk minimization, which is relevant to the Muslim consumer cultural lens and Islam. The halal paradigm is a nub where the perceived importance of halal is brought into the Muslim consciousness. This is a dynamic and cyclical process, whose final verdict is finite and perishable, due to hypersensitivity and environmental factors influencing Muslim perceptions of what is halal (Wilson and Liu, 2011).

\subsection{Economic Growth}

This research attempts to increase economic growth whose focus is on improving the quality of consumption through the implementation of Halal At Thayyib. The fulfillment of basic needs will bring good quality to human resources, to liberate people from poverty. Additionally, many studies confirm that poverty is an important factor in economic growth (Kheir, 2018; Sasmal \& Sasmal, 2016; Sehrawat \& Giri, 2016). Poverty is a situation where the annual income of individuals in an area cannot meet the minimum expenditure standards required by individuals to be able to live properly in the region. Individuals living below the minimum expenditure standard are classified as poor. When the economy develops in a region, i.e., a certain smaller country or region, there is more income to spend, which if well distributed among the population of the region will reduce poverty. In other words, theoretically, economic growth plays an important role in overcoming the problem of poverty reduction. Economic growth is a necessary condition for poverty reduction. The sufficient condition is that this growth is effective in reducing poverty. That is, this growth should spread to every income group, including among the poor (growth with equity) (Lewis, 2013).

\subsection{Externality Theory}

Externalities occur when an individual's utility does not only depend on the goods and services consumed by the individual, but is also influenced by the activities of other individuals (Cullis \& Jones, 1992). Externalities occur because there is a difference between marginal social and private cost of an item In the case of environmental damage above it causes negative externality because there is no element of additional costs in the form of social costs included in the final item price component, therefore government intervention is needed in the form of determination taxes or subsidies to correct the effects of externalities. 
Externalities in reality have two forms: negative externalities and positive externalities (Isaksen, Brekke, \& Richter, 2019). When negative externalities occur, the price of goods or services does not perfectly reflect the additional social costs of the resources allocated in production, i.e., marginal social costs. When there is a positive externality, the price is not the same as the additional social benefits of the existing goods and services, i.e., marginal social benefits.

\subsection{Previous Studies}

Previous researchers related to consumption based on the halal concept have carried out several studies. The first research was carried out by Afzaal Ali, Guo Xiaoling, Mehkar Sherwani, and Adnan Ali in 2017, entitled 'Factors affecting Halal meat purchase intention: Evidence from international Muslim students in China'. This study aims to determine the determinants of consumption of halal meat in the international Muslim student population in China. Subsequent research is research conducted by Poppy Arsil, Yeong Sheng Tey, Mark Brindal, Cun Uei Phua, Denisa Liana in 2018 entitled 'Personal values underlying halal food consumption: evidence from Indonesia and Malaysia'. This research attempts to uncover personal values that drive consumption decisions of Indonesian and Malaysian Muslims on halal food. Then, research conducted in the same year by Nur Asnawi, Badri Munir Sukoco, and Muhammad Asnan Fanani, entitled Halal products consumption in international chain restaurants among global Moslem consumers. This research was conducted to investigate the determinants of global Muslim consumers in consuming halal products in international chain restaurants. Then research conducted by Abdalla Mohamed Bashir in 2019. This research entitled 'Applying the Institutional Theory at the Level of Halal Consumers: The Case of Cape Town in South Africa' aims to determine the decision to purchase halal products by consumers in Africa (Bashir, 2019).

A number of studies that have been carried out, most of them hold halal discussions related to consumption products, both food and other consumer goods. This research is the first research that attempts to explore the concept of halal directly from the main source of Islamic law by using a typical analysis tool of Islam, as well as linking it directly to the ethics of consumption, as well as its impact on economic growth.

\section{METHODOLOGY}

This study is a descriptive qualitative with content analysis. According to Berelson (1952) in (Stemler, 2001), content analysis can be systematically defined as a replication technique used to clarify words from a text into several payload categories, based on the implicit rules. Meanwhile, according to Holsti (1969) in (Stemler, 2001), content analysis is defined as a technique for interpreting and identifying a message characteristic specifically, objectively and systematically. Content analysis is research that is an in-depth discussion of the contents of written information so that the message's purpose can be obtained. Because this study uses the Quran as the subject of research, the method used to explore it must be appropriate. 
In approaching that content analysis, the authors use a method of tafsir that has been used by Ulama' to explore the laws and wisdom from Quran. In this case, the authors combine between tafsìr bi al-ra'yi and tafsìr bi al-ma'thūr. This refers to the opinion of al-Suyūtī and al-Qardāawi aforementioned, that the interpretation with modern science should still refer to the naș and tafsìr bi al-ma'thür as well. Therefore, this research explores some of the leading tafsì literary, both classical and contemporary tafsìr. The classical tafsìr books that the authors used as reference are Tafsì Ibn Kathīr by Ismā'îl bin 'Umar bin Kathīr, Ma'ālim al-Tanzìl by Abū Muhammad al-Husain

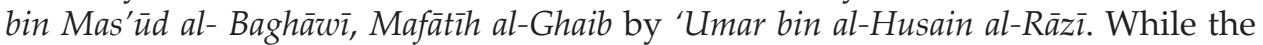
contemporary tafsīr books, used as reference are Tafsìr al-Munīr by Dr. Wahbah alZuhailī and Tafsìr al-Sha'rāwō by Muhammad Mutawallì al- Sha'rāwīi

\section{RESULTS AND ANALYSIS}

\subsection{Results and Analysis}

This section consists of presentation of all the results in tables, graphs, etc. and the description of those numbers and figures. The discussion of this research is divided into three main topics: (1) the basic concept of consumption, (2) the concept of Halal and Tayyib as an object of consumption, and (3) Consumption Behavior Concepts.

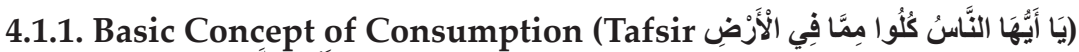 4.1.1.1. Tafsir يَا أَيْهَا النَّاسن}

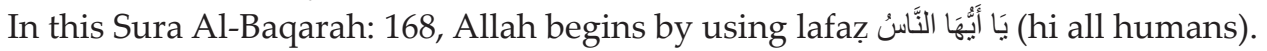
The use of lafaz shows that the commands contained in this verse include all human beings both mu'min and unbelievers (Al-Zuhaili, 1998). This is part of God's grace and blessing to all humanity, where Allah created all that is on this earth for human beings whether they are believers or infidels. Explicitly, this verse seems to have a message to unbelievers, that with His love, God commands and shows them to consume everything that is lawful and good. This is nothing but their own good and benefit, in which Allah does not forbid unless something dangerous and does not justify except something good (Sha'ra $>$ wi $>$, n.d.).

The reality and history that exists reinforce such a contention, in which a lot of the Sharia that Allah has set is adopted by non-Muslims even though it is not in the form of a religion but is implemented in an order and the rules they make. One example that we can learn in this case is that it is forbidden to consume carcass meat, i.e., animals that die without sharia-compliant slaughter, which pose a danger to the health of the human body. Animals have two types of blood vessels, veins and arteries, whereas the blood before entering the kidney or lungs is dirty blood. In this case, the slaughtering process is able to drain and bleed both dirty and non-blood. Thus, the meat is clean. Unlike animals that are not slaughtered, the meat is not clean from dirty blood which endangers health (Sha'ra>wi $>$, n.d.). 


\subsubsection{Tafsir}

In Arabic grammar, lafadz sَّ means fi'il amr (command word) that has Lafaz derived from mashdar (basic words) اكل which means meal. The use of lafadz does not mean to limit the use of something lawful command to eat alone, including all forms of action and other consumption activities, as it exists in terms of economics. The use of lafadz كلو , which means eating because eating is an act of consumption the most numerous and most urgent, is used in making use of something (Andalusī, 2001).

Furthermore, Imam Ghazali to drive what many scholars who claim that eating is one part of the religion (Ghazālì, n.d.). He argued that mankind is met by God to reach His good pleasure. Ridha Allah cannot be achieved except by science and charity. Honor science and charity cannot be done except with a healthy and happy body, while health and safety agencies will be achieved by reinforcing the food consumed by the needs. Ultimately, in Surah Al-Mu'minun: 51, God says

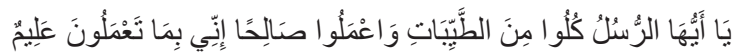

"O Messengers, eat the food that was good, and the good works. Verily I Knower of what you do "(QS. Al-Mu'minun: 51)

According (Dimashqi, 1999), in the verse Allah commands the apostles to eat kosher and simultaneously work righteousness. Thus, the verse signifies that kosher food can help good deeds.

The command word (fi'il amr) in the Qur'an directed to the necessity (required). However, scholars disagree whether the command word (fi'il amr) in the form 1 ' (eat) in Surah Al-Baqarah: 168 directed at an obligation. According to the majority of scholars' interpretation, said orders in lafadz كلو showed no compulsory but ibāhah (allowed). Among these are (Andalusī, 2001) and (Nasafì, 2005). However, interesting aspects are put forward by (Alūsī, n.d.). In this case, the command to consume halal depends on the purpose of having such consumption. When consumption is used to strengthen joints and limbs in order to establish a life, then it should be obligatory consumption. When consumption is used for entertaining guests, then the consumption is sunnah. As for kosher consumption for purposes other than the above, it is permissible (allowed).

Based on what was presented by the imam of Al-Alusi above, we can see that consumption is an intermediary (wasilah), in which the law is very dependent main purpose of their action such consumption based on applicable fiqh references.

للوسائل حكم المقاصد

Intermediaries have the same law with the main purpose of the intermediary (Jaizāni, 2006). In this case, when the consumption is intended to meet the basic needs that are Daruri (primary), then the consumption is mandatory. Imam Shatibi defines the Daruri basic needs as everything needed for the establishment of religion and the world's benefit. Where when something is not there, it will disrupt the continuity of the benefit of religion and the world and capable of causing damage, chaos, loss of life and safety, and there will be a very real loss. 
In this case there are five basic needs that are Daruri known as al-diarūriyyāt alkhams, namely the protection of religion, life, intellect, nasab or dignity, and property (Shātibīi, 1997).

\subsubsection{Tafsir مِمَّا فِي الَْأَزضِ}

According to Zamahshari, the use of lafadz su (min) in the verse denoting tab'ị̂ (partially) (Zamahshari, 1983). Use of lafadz sن (min) signifies the assertion that not everything that God has created on this earth can be consumed. However, the only objects lawful and fine allowed by God are to be consumed.

Furthermore, Sha'rāwī in response to the propaganda that has been widely echoed by those who regard the lawful and unlawful is ridiculous (Sha'rāwī, n.d.). They questioned sarcastically why God created things on this earth that ultimately forbidden. The cynical question about Sha'rāwī because they do not know for sure about the secrets and urgency that God created every creature. While secrecy and urgency is not always there when the creature is consumed. For example, snakes and scorpions are dangerous for human consumption. Nevertheless, snakes and scorpions have been very useful in the medical world that is used to kill microbes that are harmful to humans.

\subsubsection{The Concept of Halal and Tayyib as an Object of Consumption (Tafsir حَلَاًً طَيَّبَ)}

Lafaz حلالا طيبا (lawful and good) is the object of consumption of existing orders in the previous lafaz كلو (eat). With a sense Lafaz حلالا طيب (lawful and good) is the main requirement of the object that may be consumed by a human being. In more detail the concept of Halal and Tayyib is as follows:

\subsubsection{The Concept of Halal}

Lafaz حلال (kosher) linguistically means lose the bonds. Someone with a Hajj or Umrah is said to have kosher or tahallul when he was separated from the ihram bond. From this definition we figure something is said to be lawful and something lost from things that are forbidden (Al-Rāzi, n.d.) (Al-Qurthubi, 2003). In simpler words, to decree anything lawful is something that is not prohibited. In a fiqh term described

$$
\text { الأصل في الأشياء الإباحة حتى يدل الدليل على التحريم }
$$

"The law originally in everything is permissible (halal) until there is proof that describes the haram" (Suyūṭì, 1983)

Such a method proposition is reinforced by some of the Qur'an and Sunnah as follows: 
1. The arguments from the Qur'an

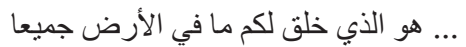

"It is God, who made everything on earth for you ..." (Qur'an, Surah AlBaqarah: 129)

ألم تروا أن الله سخر لكم ما في السماوات وما في الأرض وأسبغ عليكم نعمه ظاهرة وباطنة

"Do you not see that Allah has subjected to (interest) you everything in the heavens and on earth, and you His favors outwardly and inwardly ..." (QS. Luqman: 20)

Two verses make it clear that all that is on the earth have been created and subjugated by God for the benefit of man. This suggests that humans may use everything that exists on this earth as long as it does not conflict with the provisions and prohibitions of Allah.

In Al-An'am: 119 Allah said

وقد فصل لكم ما حرم عليكم

"... Allah has explained to you what is forbidden him upon you ..." (QS. AlAn'am: 119)

According to the priest (Sa'dī, 2000), the surah Al-An'am: 119 explains that the legal origin of the things and the food is permissible (halal) until there is proof that forbid it. This is because in the case of unlawful paragraph has been described by Allah. Thus, something that is not explained by Allah is not haram (permitted) because in Islam there are only two of the law is lawful and unlawful.

2. The arguments of Al-Sunnah

Adg

ما أحل الله في كتابه فهو حلال, وما حرم فهو حر ام, وما سكت عنه فهو عفو, فاقبلو ا من الله عافيته (وما كان ربك نسيا)

"Whatever Allah has made lawful in His Book, then he is lawful, and whatever He forbid, he is unclean; but that which he is quieted, then he is forgiven (permissible). Therefore, to receive remission of God, for behold, God will not forget at all. "Then, the Prophet read the verse: and the Lord will not forget "(HR, Judge, Tabarani and Dāruquṭnī)

سئل رسول الله صلى الله عليه وسلم عن السمن و الجبن و الفر اء فقال: الحلال ما أحل الله في كتابه, و الحر ام ما حرم

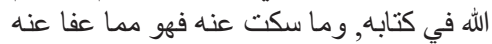


"Prophet Muhammad was asked about his legal cumin, cheese and wild donkeys, then he answered: What is lawful is something that Allah has made lawful in His Book and called unclean that God is forbidden in His Book. Being what God let stand, then he was the one that God forgive for you "(HR. Turmudhī, Ibn Majah, Hakim, and Tabarani)

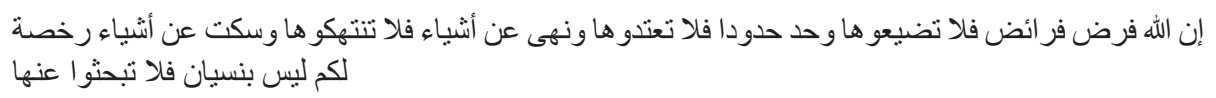

"Allah has obliged some obligations, then do not you waste it, and God has given some limit, then do not you broke down, and God forbid something, then do not you fight about him, and God has quieted some things as a favor for you, he did not forget, then don't you question it." (HR. Baihaqi)

The third hadith describes that something that is not explained by God is a forgiveness and mercy for us. This shows that everything is permissible and lawful until there is proof that explains it otherwise. Based upon knowing something lawful cannot be separated from knowing something that is forbidden because of something that means something that is not halal haram. According to Razi, when something is generally forbidden there are two kinds of reasoning (Al-Rāzi, n.d.): First, unlawful because the object is termed illegitimate li dhātihi everything that God forbidden for consumption. Haram first type has been described in the Qur'an and Hadith. Among the things that are forbidden for consumption that is mentioned in the Qur'an is

.... إنما حرم عليكم الميتة و الدم ولحم الخنزير وما أهل به لغير الله

"He hath only forbidden you dead meat, blood, the flesh of swine, and animals (when slaughtered) is called (name) besides Allah ..." (Qur'an, Al-Baqarah: 173)

يا أيها الذين آمنو ا إنما الخمر و الميسر والأنصاب و الأز لام رجس من عمل الثيطان فاجتنبوه لعلكم تفلحون

"O ye who believe, in fact (drinking) alcohol, gambling, (sacrifice to) idols, gambled with the fate of the arrow, is included acts of Satan. So shun the deeds that ye may prosper"

Second, it is forbidden not because the object is termed illegitimate lighairi dhātihi is something kosher, but be unlawful because it was obtained by unlawful. Among the ways of making something haram mentioned in the Qur'an is

يا أيها الذين آمنو ال انأكلو ا أمو الكم بينكم بالباطل إلا أن تكون تجارة عن تر اض منكم

"O ye who believe, do not eat each other neighbor's property by way of vanity, except by way of commerce that goes with the same love-love among you ..." (Qur'an, al-Nisa ':29) 
According Sa'di, it is forbidden to eat up the property by way of vanity is to take away the right of people to corrupt, stealing, gambling, usury, and shoddy work and other despicable actions (Sa'dī, 2000). In another verse, Allah has also confirmed the prohibition of usury in particular that in Surah Al-Baqarah: 275 and Al-Ma'idah: 90. God said,

وأحل الله البيع وحرم الربا

“... Allah has permitted trading and forbidden usury ..." (QS. Al-Baqarah: 275)

يا أيها الذين آمنوا إنما الخمر واليسر والأنصاب والأز لام رجس من عمل الثيطان فاجتنبوه لعلكم تفلحون

"O ye who believe, in fact (drinking) alcohol, gambling, (sacrifice to) idols, gambled with the fate of the arrow, is included acts of Satan. So shun the deeds that ye may prosper" (QS. Al-Ma'idah: 90)

\subsubsection{The Concept of Tayyib}

In language Lafaz Tayyib (طيب) by Ibn 'Ashur (1997: 6, 111) has the meaning

الطهارة والزكاء والوقع الحسن في النفس عاجلا وآجلا

"Holy, developing, and positive impact on life in the present or future"

According to Ibn 'Ashur, is thought Tayyib (طيب) when humans consume because it has a benefit in it(Ibn 'Āsyūr, 1997). In line with Ibn 'Ashur, Dimashqī interprets Lafaz țayyiban (طيب) (Dimashqi, 1999)in Surah Al-Baqarah: 168 with

مستطابا في نفسه غير ضار للأبدان ولا للعقول

"Considered both in its content and does not harm the body and mind"

Based on both such interpretations, we can conclude that something called Tayyib (طيب) when it has two main elements, which is:

First, it contains good and useful things. In the context of food, Tayyib (طيب) can be defined by food containing the nutrients that are beneficial and needed by the human body. Thus, the command to consume food that Tayyib (طب) means the command to consume food containing nutrients and the best benefits for the human body (Ibn 'Āsyūr, 1997).

Second, it does not have a negative impact for both body and mind. In the context of food, there are two types of content results that have a negative impact on the body and mind: (1) food containing ingredients have a negative impact on the body or mind that is common to all humans as food poisoning, and (2) food with a negative impact on the body or mind for some people. Food containing high levels of sugar is a good example for someone who is in good health, but has a negative impact for people who suffer from diabetes. Similarly, food that has a high salt content is good for a person in normal health condition, yet very dangerous for people who suffer from hypertension. 


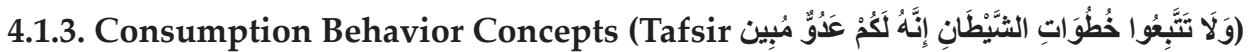

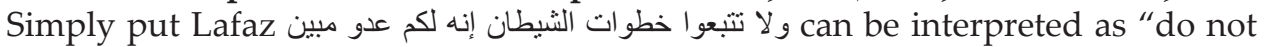
follow the steps of Satan; because the devil indeed is a clear enemy". According to Qurtubi, a devil step is everything that is contrary to the Sunnah and Sharia (Al-Qurthubi, 2003). In the Qur'an, three actions are prohibited and contrary to the sharia in terms of consumption, namely:

First, tabdhīr (التبذير) as mentioned in Surah Al-Isra ‘: 26-27, God says

و لا تبذر تبذيرا (26) إن المبذرين كانوا إخوان الثياطين وكان الثيطان لربه كفورا (27) ...

"... And do not squander (your wealth) in wantonness (26) Lo-waster wasters that are brothers of Satan and the devil it is ingrate to his Lord (27)" (QS. Al-Isra ': 26-27).

According to Ibn Mas'ud Companions as narrated by Bayhaqi (2003: 8 490), which meant tabdhīr (التبذير) is

إنفاق المال في غير حقه

"Using the property for other than the right"

In other words tabdhīr (التبذير) is the use of something that is not appropriate even though in small amounts.

Second, israf (الاسر اف) as mentioned in Surah Al-A'raf 31, Allah says

وكلو ا واشربو او لا تسرفوا إنه لا يحب المسرفين ....

"... Eat and drink, and do not be exaggerated. Allah loves not those who exaggerated" (QS. Al-A'raf 31).

Simply put israf (الاسر اف) can be confused with exaggerated beyond what is needed. According to Sa'di (2000: 267), excessive here could be in the form of more than enough levels, greedily consume food that can harm the body, or extravagance in food and beverages.

Third, taqtīr (التقتير) as mentioned in Al-Furqan: 67, God says

و الذين إذا أنفق الم يسرفو ا ولم يقتروا وكان بين ذلك قو اما

"And those who when they spend (treasure), they are not excessive, and not (also) a miser, and is (spending it) in the middle between such" (QS. Al-Furqan: 67).

According to Dimashqī, a kirir or taqtīr (التقتير) is the opposite of excessive or israf (الاسر اف), which is to consume something less than its needs, so it is insufficient. 


\subsubsection{Impact of Halal and Tayyib on Macro Economy}

\subsubsection{The Impact on Economic Growth}

We can see from the theory of the vicious cycle of poverty in development economics proposed by Gunnar Myrdal (Al-Faizin \& Akbar, 2018) the impact of the consumption of Halal and Tayyib. According to Gunnar Myrdal, poverty is not merely a problem of capital shortage of the poor. Conversely, more poverty is caused by unmet basic needs of the poor, especially in the case of poor nutritional quality. Furthermore, he explained that the poor condition stems from a low income in that the nutritional quality becomes less. The low quality of these nutrients leads to low health, which leads to lower productivity. Such low productivity causes a low income, and in turn leads to poverty. This situation will continue to be repeated in that the poor will not get out of poverty. According to Myrdal, to eradicate poverty we must break the cycle over by meeting the basic needs of the poor, especially in terms of nutrition and health.

\section{Figure 1. The Gunnar Myrdal's Version of Vicious Cyrcle of Poverty}

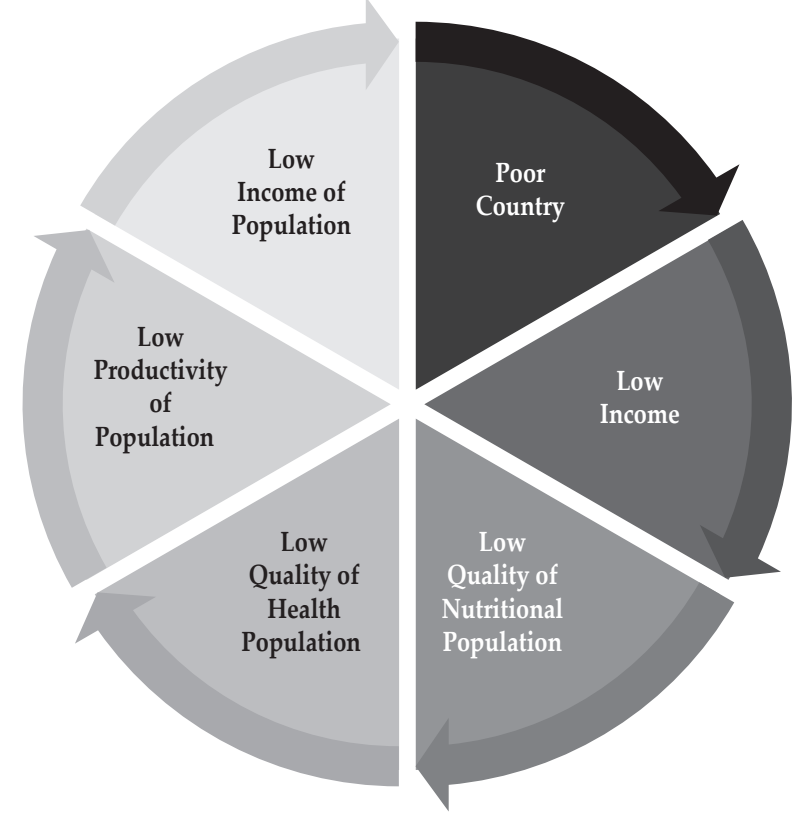

Source: (Al-Faizin \& Akbar, 2018)

As explained previously that order to consume something that is lawful and Tayyib is a command to consume food containing nutrients and the best benefits for the human body (Ibn 'Âsyūr, 1997). In so doing, the consumption of halal food and Tayyib is able to improve the nutritional intake of society that can ultimately improve their health. Public health is then able to increase their productivity, which in turn is also able to increase their income. With such a high income, growth and economic development of a country will be achieved. In simple terms the impact of that kosher, food consumption and Tayyib we can see in the following diagram. 
Figure 2. Consumption of Halal and Tayyib Impact for the Economy

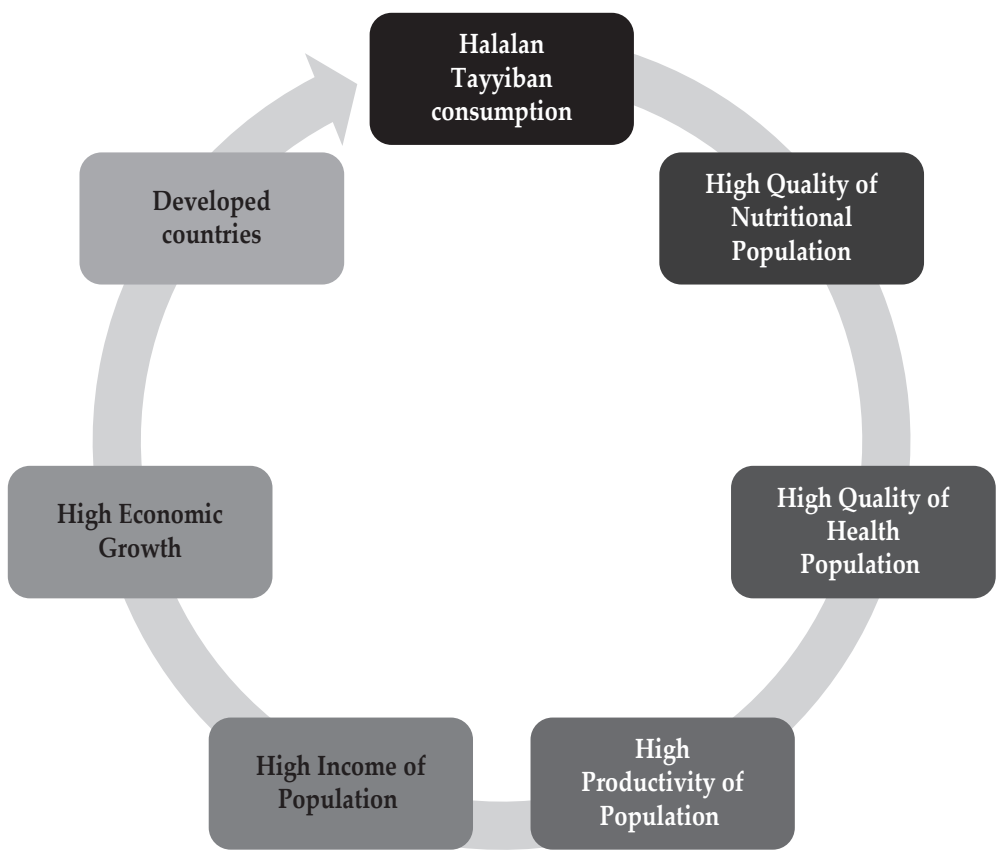

Source: modified model of the vicious cyrcle of poverty Gunnar Myrdal (Author, 2018)

\subsubsection{Halal at Thayyib and Externalities}

In the context of the public economy, consumption of something halal and tayyib does not cause negative externalities. In contrast to the consumption of something that is unclean or not tayyib which often causes negative externalities for others. In the Qur'an one of the negative externalities caused by the consumption of unclean and described in Tayyib al-Ma'idah : 91, God says:

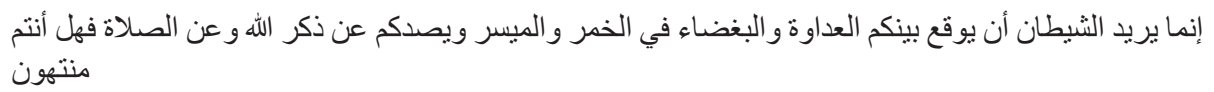

"He is an intended going to cause enmity and hatred between you because (drinking) wine and gambling, and hinder you from the remembrance of God and prayer; then stop you (from doing the job) " (QS. Al-Ma'idah: 91)

In Surah Al-Ma'idah: 91 above, Allah mentions two forms of negative externalities caused by khamr consumption (haram li dhatih) and gambling (haram li ghairihi) antagonism and hatred. According (Sa'dī, 2000) khamr consumption can eliminate a person's mind and consciousness that prompted him to revile and despise the people around him so often end up with the infighting and hostility, even to murder. Similarly, the gambler makes one side wins and gets a lot of money, and the other party loses and gets a big loss without any compensation. This often makes enmity, discord and even murder between the two parties. 
In public economics, negative externalities in the form of hostility and hatred as described above can cause enormous economic costs that will eventually hamper economies. The economic costs such as costs due to destruction of assets and the recovery and treatment of the warring parties. Even in a large scale hostility and hatred is not uncommon to disrupt political stability nationwide.

\subsection{Robustness Test}

Since this research uses a qualitative research approach, the source of which is the literature, the research has attempted to examine it using relevant books to support the analysis. Moreover, this research is supported by studies that support its empirical analysis.

\section{CONCLUSION AND RECOMMENDATION}

\subsection{Conclusion}

Consumption is one of the main pillars of Islamic economics, especially with regard to the five basic needs in the maqāssid sharia. Three main aspects of an object said by Halal at Thayyib are the main condition of the object of consumption in Islam. First, it does not contain illicit elements. Second, it contains benefits that have a positive impact. Third, it does not contain anything that is harmful to the body and mind. This study also found that macro consumption is something that Halal at Thayyib is able to improve quality economic growth by eliminating negative externalities.

\subsection{Recommendations}

In the end, the results of this study can be used as a reference for regulators to develop regulations related to consumption. Both regulations and community institutions or other relevant institutions could provide educational information effectively and efficiently. Furthermore, with the collaboration of academics and practitioners it can be formulated an assessment form for producers of consumer goods and services, so that it can be used as a reference for banking institutions in assessing the feasibility of financing. Of course, this can be done with good cooperation from the parties. Furthermore, this research portrays a conceptual argument limited to the interpretation of one verse. Further research needs to be made with empirical evidence to reinforce the concepts offered in this study.

\section{REFERENCES}

Abdelali, A. P. D. B. Z. (2019). Syariah Compliance on Halal Food Based on Certain Ayat in Surat Al-Ma'idah. E-Journal Of The 6th Arabic Studies \& Islamic Civilization.

Al-Faizin, A. W., \& Akbar, N. (2018). Tafsir Ekonomi Kontemporer: Menggali Teori Ekonomi dari Ayat-Ayat Al-Qur'an. Jakarta: Gema Insani Press.

Al-Qurthubi. (2003). al-Jāmi' li Ahkām al-Qur'ān. Riyadl: Dār 'Âlam al-Kutub.

Al-Rāzi. (n.d.). Mafātih al-Ghaib. Mauqi' Al-Tafāsīr. 
Al-Zuhaili. (1998). Tafsīr al-Munīr fi al-'aqīdah wa Al-Syarī'ah wa al-Manhaj. Bairut: Dār al-Fikr.

Ali, A., Xiaoling, G., Sherwani, M., \& Ali, A. (2017). Factors Affecting Halal Meat Purchase Intention: Evidence From International Muslim Students In China. British Food Journal, 119(3), 527-541.

Alūsī, A. al-F. M. al. (n.d.). Rūh al-Ma'āni fi Tafsīr al-Qur'ān al-'Azīim wa al-Sab' alMathāni. Bairut: Dār Ihyā' al-Turāth al-'Arabī.

Andalusī, M. bin Y. al. (2001). Tafsìr Bahr al-Muhī. Bairut: Dār al-Kutub al-'Ilmiyyah. Arsil, P., Tey, Y. S., Brindal, M., Phua, C. U., \& Liana, D. (2018). Personal Values Underlying Halal Food Consumption: Evidence from Indonesia and Malaysia. British Food Journal.

Asnawi, N., Sukoco, B. M., \& Fanani, M. A. (2018). Halal Products Consumption in International Chain Restaurants among Global Moslem Consumers. International Journal of Emerging Markets, (just-accepted), 0.

Ayyub, R. M. (2015). An Empirical Investigation of Ethnic Food Consumption: A Perspective of Majority Ethnic Group. British Food Journal, 117(4), 1239-1255.

Bashir, A. M. (2019). Applying the Institutional Theory at the Level of Halal Consumers: The Case of Cape Town in South Africa. Journal of Food Products Marketing, 1-22.

Cullis, J. G., \& Jones, P. R. (1992). Public Choice and Public Finance: Analytical Perspectives. McGraw-Hill.

Dimashqi, I. bin ‘Umar bin K. al. (1999). Tafsīr al-Qur'ān al-'Az\{ìm. Dār Taybah.

Ghazālī, A. H. M. bin M. al. (n.d.). Ihya' Ulūm al-Dīn. Bairut: Dār al-Ma'rifah.

Ibn 'Āsyūr, M. al-Ṭāhir. (1997). Al-Tahrīr wa al-Tanwīr. Tunisia: Dār Sahnūn.

Isaksen, E. T., Brekke, K. A., \& Richter, A. (2019). Positive Framing Does Not Solve The Tragedy of The Commons. Journal of Environmental Economics and Management, 95, 45-56.

Jaizāni, M. bin H. (2006). Ma'ālim Ușūl al-Figh 'Inda Ahli al-Sunnah wa al-Jamā'ah. Dār ibn al-Jauzī.

Kheir, V. B. (2018). The Nexus between Financial Development and Poverty Reduction in Egypt. Review of Economics and Political Science, 3(2), 40-55.

Lewis, W. A. (2013). Theory of Economic Growth. Routledge.

Nasafī, 'Abdullah bin Ahmad al. (2005). Tafsīr al-Nasafì. Bairut: Dār al-Nafāis.

Omar, N. A., Zainol, Z., Thye, C. K., Ahmad Nordin, N., \& Nazri, M. A. (2017). Halal Violation Episode: Does Severity and Trust Recovery Impact Negative Consumption Behavior? Journal of Islamic Marketing, 8(4), 686-710.

Petach, L. A., \& Tavani, D. (2019). Consumption Externalities and Growth: Theory and Evidence for the United States. Journal of Economic Behavior E Organization.

Sa'dī, 'Abdurrahman bin Nāșir al. (2000). Taisīr al-Karīm al-Rahmān fi Tafsìr Kalām al-Mannān. Bairut: Mu'assasah al-Risālah.

Sasmal, R., \& Sasmal, J. (2016). Public Expenditure, Economic Growth and Poverty Alleviation. International Journal of Social Economics, 43(6), 604-618.

Sehrawat, M., \& Giri, A. K. (2016). Financial Development and Poverty Reduction In India: An Empirical Investigation. International Journal of Social Economics, 43(2), 106-122.

Sha'ra>wi>, M. M. al. (n.d.). Tafsi>r al-Sha'ra>wi. Maktabah al-Shamilah.

Sha'rāwī, M. M. al. (n.d.). Tafsīr Al-Sha'rāwi. Maktabah al-Shāmilah. 
Shahid, S., Ahmed, F., \& Hasan, U. (2018). A Qualitative Investigation into Consumption of Halal Cosmetic Products: The Evidence from India. Journal of Islamic Marketing.

Shātịīì, I. bin M. al. (1997). Al-Muwwāfaqāt. Dār Ibn 'Affan.

Stemler, S. (2001). An Overview of Content Analysis. Practical Assessment, Research \& Evaluation, 7(17). Retrieved from http://pareonline.net/getvn. asp? $\mathrm{v}=7 \& \mathrm{n}=17$

Suyūṭị, 'Abdurrahman bin Abī Bakar al. (1983). al-Ashbāh wa al-Nazā'ir. Bairut: Dār al-Kutub al-'Ilmiyyah.

Wilson, J. A. J., \& Liu, J. (2011). The Challenges of Islamic Branding: Navigating Emotions And Halal. Journal of Islamic Marketing, 2(1), 28-42.

Zamahshari, A. al-Q. M. al. (1983). al-Kashshāf 'an Haqū'iq at-Tanzìl wa 'Uyūn alAqāwoìl fi Wujūh at-Ta'wīl. Bairut: Dār al-Fikr. 